\title{
A Tragedy of the Councils? Exploring the Hollowing-Out Hypothesis - The Case of Norwegian Local Authorities
}

\author{
DAG INGVAR JACOBSEN
}

\begin{abstract}
In the debate on governance structures, it is often assumed that traditional political and administrative institutions are "hollowed-out" in favour of other actors at the international, national and local levels. But how valid is this assumption? By using a variant of the reputational method for studying power, local politicians in 30 Norwegian municipalities were asked to assess the power of other actors in different fields - the local administration, central government, local media, local pressure and interest groups, and international institutions like the EU - in relation to the perceived power of the political local council. The main conclusion is that three main actors are clearly perceived as more powerful than other actors: the local political council, the local administration and the state. Other actors were deemed much less influential, indicating that the power of local politicians may be rather large. Findings indicate that old hierarchical government structures seem still to be highly influential. In addition, the perceived power of local authorities varies across municipalities and within them. Implications for governance studies are discussed.
\end{abstract}

KEYWORDS: • local self-government $\bullet$ governance structures $\bullet$ local authorities $\bullet$ hollowing-out hypothesis $\bullet$ Norway

Correspondence AdDress: Professor Dag Ingvar Jacobsen, Adger University College, Dep. for Economics and Social Sciences, Institute of Political Science and Leadership, Servicebox 422, 4602 Kristansand, Norway, e-mail: dag.i.jacobsen@hia.no. 


\section{Introduction}

"Perhaps the most significant development in the advanced industrialized democracies over the past couple of decades has been the erosion of traditional bases of political power" (Pierre 2000:1). In an ideal representative democracy, representatives of the people should decide on matters defined within the boundaries of the public domain, and they should stay accountable to the people, usually through elections (Lively 1975; Olsen 1983). Several students of politics at the international, national and regional/local levels seem to conclude that this description is increasingly inadequate. The rise of supranational institutions like the EU and WTO blur the distinction between national and supranational political powers, activist networks, interest groups, and non-governmental organisations take over former political responsibilities forcing politicians into "co-governance" with these actors (Bogason 2000; Kooiman 2008; Lascoumes \& Le Galet 2003; Trondal 2007). Also, the distinction between the public and the private sector, between business and politics and between civil society and the state, is blurred and complex networks of cooperation arise (Kooiman 1993). In addition, one can detect a constant weakening of political power through reforms accentuating markets, and consumers and legal systems have moved powers away from traditional democratic institutions (Lægreid \& Roness 1998; Peters 2001, ch. 9).

These trends are assumed to "hollow-out" traditional political institutions (Rhodes 1994), resulting in a shift from hierarchy to more steering through networks, horizontal relations and cooperation (Greenaway et al 2007; Lowndes \& Schelcher 1998; Pierre 1993; Rhodes 1996, 2007; Sørensen \& Torfing 2007). Studying the emergence and the functioning of such governance-institutions have clearly been one of the popular trends among political scientists and public administration researchers over the last decade (Hirst 2000:13; Klijn 2008), almost on the verge of becoming the "dominant narrative" at the expense of the narrative of traditional, hierarchical government (du Gay 2002).

Still, most studies of governance structures seem to take for granted that the traditional political and administrative centre has been hollowed out, that it has lost its power to other actors. This study attempts to fill this void, although limitedly, by studying a selection of Norwegian municipalities and local authorities and by using only one of many possible ways of measuring power and the so-called reputational approach providing empirical data on how politicians and local administrative leaders perceive their power relative to other institutions and actors exerting influence at the local level. Data was collected by a survey of all elected politicians in 30 municipal councils in southern Norway in 2000 and 2003. 


\section{Norwegian Local Authorities - Hollowed Out?}

Recent research on the Scandinavian countries concludes that the power of traditional, democratic institutions at the local level has diminished during the last decades, thus limiting the possibility for local steering and leadership. (Fimreite \& Flo 2002; SOU 1990:44; Togeby et al 2003: ch. 9; Tranvik \& Fimreite 2006; Østerud et al 2003). Five trends - here related to the Norwegian setting, but clearly relevant also in several other national settings - support this view.

The first trend is regarded as an assumed increased control and regulation of Norwegian municipalities by the state authorities. Norway, like the other Scandinavian countries, is a unitary state where local authorities are formally integrated into the national government. Although all power exercised by local government is, in principle, delegated to this level from the central government, local autonomy is clearly an ideal, arousing positive notions like efficiency; flexibility and participation are closely associated with decentralisation (Hagen \& Sørensen 2006). However, in a welfare state like Norway, there are strong national norms on equality across geographical territories, and the state uses several mechanisms to equal out these differences (Fimreite 2003b).

The research on the relationship between local and central government in Norway seems to conclude that the central government has strengthened its control over municipalities during the last decades. The number of formal rules and regulation regarding activities at the local level has increased (Fimreite et al 2002; Fimreite 2003b, Flo 2003, Offerdal \& Kjellberg 1997), financial control has been strengthened through a combined use of earmarked grants and economic incentives (Hagen \& Sørensen 2006, Østerud et al 2003), and the use of direct control from both ministries and even the Parliament has intensified (Hansen et al 2000). Some researchers even conclude that the present relationship between local and central government is characterised by "strong national integration (central government control) and little local leeway" (Fimreite 2003b:342), and that recent reforms to increase local autonomy should be viewed as failures in that respect (Tranvik \& Fimreite 2006). In an international perspective, Norwegian local authorities also seem to be strongly under the control of central government (Sellers \& Lidstrøm 2007). In general, the conclusion seems to be that the central government has increased its control over local authorities, leaving fewer discretionary options to local decision makers.

The second trend is viewed as a constant delegation of powers from political to administrative spheres. Norwegian local authorities have not been shielded from the influence of the reforms associated with the so-called New Public Management (NPM) trend (Jacobsen 2007; Johnsen 1999; Øgård 2000). Recent research on political activity in Norwegian local authorities shows some fairly clear trends. First, the workload of municipal councils seems to be decreasing, 
measured in the numbers of decisions taken by the council (Hovik \& Stigen 2004; Vabo 2002; Vabo \& Stigen 2000). Many responsibilities have been delegated to the administration, leaving local politicians to focus on a few strategic issues, but cutting them off from day-to-day activities in the authority (Berg 2000, Vabo 2002). Secondly, organisational reforms in the local authorities seem to have increased administrative freedom from political control. De-specialisation of political councils to avoid "sectorial thinking" has diminished the possibility to control a highly specialised administration by increasing the "competence gap" between elected politicians (Baldersheim 1998:131; Jacobsen 1997; 2007). At the service providing level, new organisational forms guaranteeing stronger administrative freedom proliferate. Administrative units, defined as "divisions", "result units" or "public business units" are granted more discretionary power, and are governed more through contracts and result control than through direct political control (Opedal et al 2002). In addition, there may be an interaction between the degree of national control and the local administrative power (Jacobsen 2003). In strongly regulated sectors, the local administration may legitimately act as administrators of nationally drafted rules and regulations, tilting the power further in favour of the administration. As a conclusion, it seems as though local political bodies have been "hollowed out" in favour of the local administration.

The third trend stems from observations of a change in political activity in Norwegian municipalities. On the one hand, public participation in formal institutions like political parties and elections is steadily decreasing (Bjørklund \& Saglie 2000). This may be interpreted as a decrease in the legitimacy of formal political institutions at the local level (Offerdal 2003; Saglie 2005). On the other hand, while voter turn-out reached an all-time low, more informal political activity was more prominent than ever before, a picture reinforced by the local elections in 2003 (Bjørklund \& Saglie 2000; Saglie \& Bjørklund 2005). Inhabitants in Norwegian municipalities, to a stronger degree, exert a direct influence, such as taking direct contact with specific politicians or administrative leaders to speak their views, and by engaging in activities such as public demonstrations and petitions. Following Olsen (1988), one may argue that this increased direct control activity exerted by the public may change the mandate of politicians, altering it from a rather free mandate, where they only have to stand responsible to the electorate every four years in formal elections, into the bound mandate where political activities are monitored by the public in more detail during the whole election period. Thus, one may hypothesize that increased direct public control and interest have decreased the possibilities to exert political discretion during an election period.

The fourth trend refers to the seemingly increased media power in modern societies (Sussman 1997). Media consumption increases and media channels are multiplying. It has been argued that mass media are becoming an increasingly 
important political factor, determining the political agenda, putting pressure on political decision makers, and to a large degree determining the public interest in a certain topic or policy (Østerud et al 2003). In Norway, both national and local media have become more independent of political parties, and the journalism has become more investigative and aggressive (Hernes 1978; Østby 2000; Aardahl \& Waldahl 2004). Most Norwegian municipalities have at least one local newspaper, there are close to 150 of them, while most of the large TV-channels have local reporters. In addition, there are several local radio channels, often broadcasting directly, for instance, from political meetings in the local council. Some have argued that this has reduced the agenda setting power of politicians (Mortensen et al 1995; Ødegård 1996 \& 1997, Walgrave \& Van Aelst 2006; Østerud et al 2003).

The fifth and last trend refers to the increased importance of international and supra-national institutions in the functioning of local authorities (Nordby \& Veggeland 1999; Østerud et al 2003). It seems to be a valid conclusion to many western countries (Kjær 2004). Even if international organisations seldom relate directly to local authorities (Christensen 1996), many of the laws and regulations decided at the national level have direct implications for local authorities whether they regard rules for competitive tendering, the quality of water or the security on kindergarten playgrounds. For most politicians at the local level, these rules, although they originate from international institutions, will most likely be perceived as coming from the national government.

The trends described previously are general in nature, resulting in a general conclusion: local authorities have been hollowed out. Such a conclusion leaves several questions open. The first question is how dramatic this hollowing out is. Are we talking of a situation where local politicians feel themselves totally powerless, or is the picture more nuanced? Perhaps some politicians, some councils, some local authorities have lost less power than others? This leads us to the next question: Under which conditions does hollowing out seem to be strongest (or weakest)? Empirical studies on Norwegian municipalities indicate that there are large variations between municipalities, and even within municipalities. For instance, the perceived strength of state regulations vary clearly among local politicians according to their financial strength (Jacobsen 2007), informal political activity varies much between large and small municipalities (Saglie \& Bjørklund 2005), and the pressure of both interest organisations and media differ between sectors in the same local authority, as does the perceived state level pressure (Hagen \& Sørensen 2006). These findings indicate that hollowing out is not only a matter of degree, but also of variation between entities at several levels.

To answer these questions, at least partially, we need to find out how powerful local politicians find themselves in relation to other relevant actors constituting the five trends described above. And we need information on to what extent it is 
possible to detect variation both between and within local authorities. We have to set the focus on power.

\section{Studying the Perceived Power}

How to study power has been a hotly debated topic for more than 50 years (Bachrach \& Baratz 1962 \& 1963; Engelstad 1999; Mintzberg 1983; Friedrich 1937; Stone 1989). In recent years, the confrontation has seemed to be between those still using an actor-centred approach, and thus favouring a more structural approach (Clegg et al 2006). An actor-centred approach to power will focus on actors, their intentions and the resources and activities they use for obtaining the objectives (Barry 1980a \& 1980b; Pfeffer 1981 \& 1992). The structural approach focuses more on the embedded nature of power, such as in structures, language and taken-for-granted norms and assumptions (Clegg 1989 \& 2006; Lukes 1974; March 1988; Stone 1989). It seems impossible to decide whether any of the approaches are theoretically superior, and recent discussions seem to conclude that the approaches are more complementary than competitive (Clegg 2006; Dowding et al 2001; Stone 2006b). This study uses and actor-centred approach, and it will thus be better suited to measure the "open face" of power, i.e., the power embedded in formal positions and participation in open processes regarding collective outcomes (Clegg, Courpasson \& Phillips 2006).

The most common ways of measuring actor-based power is through the "decisional school of power studies". In short, these studies identify certain policy areas, and then they identify the participants in the arenas where decisions about these policy areas are made. The more arenas a person participates in, the more powerful he or she is deemed to be (Banfield 1961; Conway 1973; Dahl 1961; Hunter 1963; Long 1958). A modernisation of this approach is to be found in network studies (Benjamin et al 2003; Grønmo \& Løyning 2003). This approach was criticized for only focusing on formal and open participation in decisions, and thus losing the use of power associated with keeping topics away from public discussion (Bachrach \& Baratz 1962 \& 1963). It is also criticized for overlooking any informal actors, and for not being open to the possibility that participation in formal arenas was more closely related to rituals and symbols than the exertion of power (Presthus 1964; see also Bonjean \& Olson 1964 for an overview).

As a response, some scholars started combining the mapping of participation in different arenas with more subjective indicators on how people perceived a person's or an actor's actual power. These studies soon came under the heading as the "reputational approach" (Hunter 1963). The strong side of these studies was their ability to identify informal powerful actors not always involved in formal decision making. However, these studies were heavily criticized for being irrelevant because being rumoured to be powerful was clearly not the same as 
actually being powerful (Bonjean \& Olson 1964:285-286; Kaufman \& Jones 1954; Wolfinger 1962).

More recent studies indicate a rather high correlation between decisional and reputational indices of power (Brass 1984; Enz 1989; Jun \& Armstrong 1997; Krackhardt 1990; Pfeffer 1981:59-61). That the correlation is far from being perfect may indicate that different approaches measure different aspects of power. Perrow (1970) argued that participation in formal decision arenas should be viewed more as a measurement of potential power, while having a reputation of being powerful was more closely connected to the actual use of power. Enz (1989:250) concludes that issue-specific measures of reputational power was more closely related to potential power, while more overall reputational indices were better for measuring an actor's actual exertion of power. Gioia \& Sims (1983:2023), in a more micro-oriented approach, established a rather strong correlation between a person's use of different power techniques (behaviour) and the same person's reputation for being powerful. Others again argue that having a reputation for being powerful is an important base of power in itself, concluding that " the wheel has turned full circle on "reputational power": it is theoretically legitimate and important" (Dowding et al 1995:274).

This study uses a variation of the reputational approach to power, asking elected politicians how they perceive the influence of different groups of actors (institutions) in the municipality. Following Enz (1989), the empirical indicators were rather general, asking questions about a group's influence on the general development of the municipality and the group's ability to determine the political agenda in the municipality.

When using a reputational approach, it becomes crucial to discuss whose opinions one is tapping. In an ideal methodological world, one would want the opinions of as many relevant actors as possible (Dahl 1961). The more diverse and independent actors agree on who is powerful and who is not, the higher degree of inter-subjectivity is obtained, resulting in higher validity.

\section{The Empirical Study}

On an aggregate level, 30 municipalities in the southern part of Norway provide the context of the study. All these municipalities are organized according to the same basic principles, closely resembling the American council-manager form (Mouritzen \& Svara 2002), a form gaining momentum in the US (Fredrickson et al 2003:8). There are direct elections to the council every four years, after each election an executive committee is formed and a mayor is elected. There is a strong formal division between politics and administration, and the CEO is an appointed position with sole responsibility for the whole administration and service provision. The last municipalities in the sample range from 70000 to a 
little more than 1000 inhabitants, with a mean of 10000. Their responsibilities are mainly connected to schooling, health- and social services, as well as roads, water provision, libraries, etc.

To measure the perceived power, questionnaires were distributed in two waves to all elected politicians in the 30 municipalities with a three-and-a-half-year span between them. This sample poses, at first sight, some problems for the aforementioned sample diversity and thus the inter-subjectivity and validity of the findings. In particular, one can argue that when asking people to report on their own power, they will have a tendency to overestimate it (Bonjean \& Olson 1964). It seems reasonable to assume that politicians will be geared towards the belief that they have power, otherwise it makes no sense for them to engage in politics. However, if municipalities are hollowed out, it seems plausible that this reality will become evident when politicians have gained some experience practising as politicians in the councils. Especially for new politicians, those elected for their first period - and in this sample, more than $40 \%$ of the politicians are first timers - we can assume that the impression of political councils being hollowed out will be stronger at the end of the term than at the beginning. Experience will serve as a "reality check", and thus it could be expected that the newcomers will be less optimistic about the power of local political councils at the end of an election period. Those elected for a second period or more are likely to express a more stable impression of the councils' power.

Secondly, it may be argued that measuring opinions within only one group yields too little diversity. This objection is based on a notion that the group "politicians" is homogenous. Such a notion is only partly true as long as it is, for instance, composed of representatives from ten different political parties, 30 very different municipalities, $40 \%$ women and $60 \%$ men, education ranging from no more formal education than basic schooling to master level, age ranging from 19 years to 76 , and occupation as varied as teachers, business consultants, bank clerks and nurses, and unemployed as well. Although they are not a perfect microcosmos of the population at large, the variation within the group of politicians is great. What they have in common is that they are politicians.

These municipalities in the study roughly represent the Norwegian municipalities in geographical, economic and political terms, and should thus be fairly representative of the Norwegian municipalities. It is difficult to generalize from the Norwegian setting to other countries. All the time, Norway is a country with very strong local government (Sellers \& Lidstrøm 2007), with long tradition of locating large powers in the public sector, and with a strong economy to back up this power. This may make hollowing out of Norwegian municipalities less likely than what could be the case in other countries with weaker institutionalization of local government. However, the argument of hollowing out is to a large degree universal, not distinguishing between, for instance, strong and weak local 
institutions. The findings from this study may say something about the limits of generalizability of the argument.

The first survey took place in the early spring of 2000, less than eight months after the municipal elections in September 1999. The second wave of questionnaires took place in the early summer of 2003 , just four months before new elections in September 2003. Initially, if one contends that hollowing-out is a continuous process, one could expect perceptions of the power of the traditional political and administrative institutions to decrease in the period. However, to have an impact on power for the trends described before, a time-span of three years is much too short. However, what is measured is the perceived power of politicians, and, as discussed earlier, we could suspect a change taking place in the newcomer group towards a more pessimistic view of the local council power if the councils are "hollow" institutions.

Politicians asked in the two waves are the same in both studies. In total for the period there were 799 politicians in 30 councils. In 2000, 540 of them responded (response rate 68), and in 2003, 470 of them responded (response rate 59). Responses were checked against municipality (response rate varying between 48 and 89 in both years), gender and political party affiliation. Regarding the two last variables, there is no deviation between the population and the actual samples. On the whole, both response rate and deviations along the mentioned variables seem acceptable.

Two general questions on the influence of a number of specified groups were asked:

"Central to all politics is the ability to define the daily agenda and to see a topic that attracts a political debate. How would you rate the importance of the following groups when it comes to defining the political agenda in your municipality?"

"In general, how would you rate the importance of the following groups when it comes to influence over the general development of the municipality?"

Answers ranged from "very important" (numerical value $=4$ ) to "totally unimportant" numerical value $=0$ ). In addition, politicians were asked to evaluate the pressure from other groups through the following question:

"Many groups want to put pressure on politicians. How often do you feel that the following groups put pressure on you to take decisions you really do not want?"

Answers ranged from "very often" (numerical value $=4$ ) to "never" numerical value $=0)$.

The general economy of the municipality was measured by income per capita, both from own taxation and from central government grants. Although this variable does not say anything directly about how healthy the economy is, it may be assumed that low-income municipalities are worse off than those with high 
income per capita. Municipality size is measured through the number of inhabitants. Six main groups of tasks were identified by asking respondents what their main responsibilities were, and the conducting a factor-analysis: a) only administrative tasks, b) health and social services, c) education and kindergartens, d) business development and agriculture, e) technical services and f) cultural services.

\section{Analysis}

Table 1 and 2 show the ranking given to different actors by the politicians.

Table 1: Politician's perceptions of diverse actors' ability to define the political agenda. Variation 0-4 ( $0=$ high, $4=$ low). Mean (standard deviation).

\begin{tabular}{|l|l|l|l|l|}
\hline & \multicolumn{2}{|c|}{ Politicians } & \multicolumn{2}{c|}{ Administrators } \\
\hline & $\begin{array}{l}2000 \\
(\mathrm{~N}=537)\end{array}$ & $\begin{array}{l}2003 \\
(\mathrm{~N}=470)\end{array}$ & $\begin{array}{l}2000 \\
(\mathrm{~N}=314)\end{array}$ & $\begin{array}{l}2003 \\
(\mathrm{~N}=337)\end{array}$ \\
\hline Local politicians & $3,17(0,82)$ & $3,06(0,82)$ & $2,72(0,89)$ & $2,61(0,81)$ \\
\hline Local administration & $3,04(0,76)$ & $3,12(0,70)$ & $3,21(0,66)$ & $3,19(0,61)$ \\
\hline \multicolumn{1}{|c|}{ State } & $2,20(0,88)$ & $2,23(0,89)$ & $2,59(0,85)$ & $2,47(0,83)$ \\
\hline $\begin{array}{l}\text { Pressure } \\
\text { groups }\end{array}$ & $2,45(0,88)$ & $2,37(0,85)$ & $2,41(0,86)$ & $2,37(0,81)$ \\
\hline \multicolumn{1}{|c|}{ Media } & $2,31(1,03)$ & $2,11(0,99)$ & $2,11(1,05)$ & $2,00(0,98)$ \\
\hline $\begin{array}{l}\text { International } \\
\text { institutions }\end{array}$ & $1,14(0,82)$ & $1,10(0,76)$ & $1,05(0,90)$ & $1,12(0,81)$ \\
\hline
\end{tabular}

Table2: Politician's perceptions of diverse actors' ability general influence on the development of the municipality. Variation $0-4 \quad(0=$ strong, $4=$ weak). Mean (standard deviation).

\begin{tabular}{|l|l|l|l|l|}
\hline & \multicolumn{2}{|c|}{ Politicians } & \multicolumn{2}{c|}{ Administrators } \\
\hline & $\begin{array}{l}2000 \\
(\mathrm{~N}=537)\end{array}$ & $\begin{array}{l}2003 \\
(\mathrm{~N}=470)\end{array}$ & $\begin{array}{l}2000 \\
(\mathrm{~N}=314)\end{array}$ & $\begin{array}{l}2003 \\
(\mathrm{~N}=337)\end{array}$ \\
\hline Local politicians & $2,61(0,84)$ & $2,64(0,81)$ & $2,71(0,81)$ & $2,71(0,74)$ \\
\hline Local administration & $2,82(0,73)$ & $2,95(0,70)$ & $2,77(0,71)$ & $2,94(0,68)$ \\
\hline \multicolumn{1}{|c|}{ State } & $2,88(0,88)$ & $2,83(0,82)$ & $2,93(0,80)$ & $2,73(0,81)$ \\
\hline $\begin{array}{l}\text { Pressure } \\
\text { groups }\end{array}$ & $1,78(0,75)$ & $1,76(0,73)$ & $1,99(0,82)$ & $1,98(0,75)$ \\
\hline \multicolumn{1}{|c|}{ Media } & $1,69(0,87)$ & $1,66(0,88)$ & $1,81(0,95)$ & $1,75(0,90)$ \\
\hline $\begin{array}{l}\text { International } \\
\text { institutions }\end{array}$ & $1,04(0,85)$ & $1,15(0,86)$ & $1,04(0,91)$ & $1,15(0,86)$ \\
\hline
\end{tabular}


There are few significant changes between 2000 and 2003. The strongest is in fact a significant decrease in new politicians' perception of the influence of mass media, and an increase in the same group's perception of the general influence of the local administration. It is also difficult to find any clear differences between newcomers and the more experienced groups of politicians. If anything, there is a slight convergence in the two group's perceptions of the influence of the different actors. But the general picture is of stable perceptions of the influence of various actors, supporting the notion that the findings are robust.

When it comes to defining the agenda, local politicians and the administration are clearly viewed as the most influential. Also, other local actors such as pressure groups and media rank higher on the ability to define the agenda than does the state level. However, when it comes to general influence, the state level is viewed as very important, but scarcely more important than local politicians and the local administration.

To make the analysis even simpler, the two questions were collapsed into one index measuring aggregated power, i.e., both over the agenda and general influence. The index was divided by two (the number of items) to obtain the same variation as the original questions in order to facilitate the interpretation. Since there were rather small differences over time and between the two groups of politicians, both years and groups were grouped together, making a global ranking of the influence of the different possible.

Table 3: Politician's global ranking of the influence of different actors in the community. Variation 0-4 (0=low, $4=$ high). Mean (standard deviation). $\mathrm{N}=1007$

\begin{tabular}{|l|c|c|}
\hline & Mean (std.dev.) & Ranking \\
\hline Local administration & $3,0(0,6)$ & 1 \\
\hline Local politicians & $2,9(0,7)$ & 2 \\
\hline State & $2,5(0,7)$ & 3 \\
\hline Pressure groups & $2,1(0,7)$ & 4 \\
\hline Media & $1,9(0,8)$ & 5 \\
\hline International institutions & $1,1(0,7)$ & 6 \\
\hline
\end{tabular}

All differences, except between "local politicians" and "local administration", between rankings are significant at the $1 \%$-level. Clearly, the politicians define a power-core" in the municipality consisting of three actors: local politicians, local administration and - somewhat more peripheral - the state level. A second group consisting of pressure groups and media constitutes another important group, but far less important than the core group. And at last, international institutions are viewed as having very little influence in the municipalities in the study. 
To find out whether there is a variation between different types of municipalities, different sectors in the municipality, a simple bivariate correlation analysis was conducted. ${ }^{1}$

Table 4: Bivariate correlations (pearson's r) between the perceived influence of different groups and municipality size, income per capita and sector. $\mathrm{N}=1005-1007 * *$ sig le. .01, * sig le .05

\begin{tabular}{|l|l|l|l|l|l|l|}
\hline & $\begin{array}{l}\text { Local } \\
\text { administrati } \\
\text { on }\end{array}$ & $\begin{array}{l}\text { Local } \\
\text { politicia } \\
\text { ns }\end{array}$ & State & $\begin{array}{l}\text { Pressur } \\
\text { e } \\
\text { groups }\end{array}$ & $\begin{array}{l}\text { Medi } \\
\text { a }\end{array}$ & $\begin{array}{l}\text { Internation } \\
\text { al } \\
\text { institutions }\end{array}$ \\
\hline Size & 0,02 & 0,02 & 0,04 & $0,11^{* *}$ & $\begin{array}{l}0,32^{*} \\
*\end{array}$ & $0,09 * *$ \\
\hline $\begin{array}{l}\text { Income per } \\
\text { capita }\end{array}$ & 0,06 & 0,04 & $\begin{array}{l}- \\
0,15^{*} \\
*\end{array}$ & $\begin{array}{l}- \\
0,11^{* *}\end{array}$ & $\begin{array}{l}- \\
0,19^{*} \\
*\end{array}$ & $-0,04$ \\
\hline $\begin{array}{l}\text { Sector: } \\
\text { Administrati } \\
\text { on }\end{array}$ & $-0,06$ & $-0,00$ & 0,00 & $-0,05$ & $-0,03$ & $-0,03$ \\
\hline $\begin{array}{l}\text { Sector: } \\
\text { Health/social }\end{array}$ & 0,03 & 0,06 & 0,05 & 0,04 & 0,00 & 0,04 \\
\hline $\begin{array}{l}\text { Sector: } \\
\text { Education }\end{array}$ & 0,03 & $0,08^{* *}$ & 0,04 & $0,08^{*}$ & 0,04 & $0,06^{*}$ \\
\hline $\begin{array}{l}\text { Sector: } \\
\text { Business }\end{array}$ & $-0,01$ & $-0,01$ & $-0,01$ & $-0,01$ & $-0,04$ & $-0,03$ \\
\hline $\begin{array}{l}\text { Sector: } \\
\text { Technical }\end{array}$ & $-0,04$ & $-0,04$ & $-0,05$ & 0,01 & $-0,04$ & $-0,03$ \\
\hline $\begin{array}{l}\text { Sector: } \\
\text { Culture }\end{array}$ & 0,00 & 0,01 & 0,01 & 0,03 & 0,05 & 0,02 \\
\hline
\end{tabular}

Both municipality size and income have effects as expected. The larger the municipality, the higher rating is given to the influence of pressure groups, media and international institutions. The correlation is particularly strong for the influence of media. The differences in perceptions between respondents working within different sectors are small, but there are tendencies for those having responsibilities for the tasks associated with education - i.e., service provision - to rank many groups higher than those working in other sectors. This may indicate a stronger pressure from external groups on persons working in this sector. Counter to the hypothesis linked to the level of state control, those primarily occupied with educational tasks do not feel state influence any stronger than those mainly responsible for other tasks. 


\section{Discussion}

According to the hypothesis that traditional political institutions have been "hollowed out", one should expect the views of politicians to support this view in the sense that they would rank themselves as less powerful than other actors. We could especially expect that newcomers into politics will get a more pessimistic view of the local council's power during the election period. Contrary to this hypothesis, local politicians place themselves together with the local administration and, to a lesser extent, the state level firmly in the power core of the municipalities. The picture emerging from the data is not of a core of the politicians having all the power, but rather a power shared with two other actors: the local administration and the state level. That these three actors are perceived almost equivalent in power can hardly be interpreted as the local political institutions have been hollowed out by the administration and the state. If that was the case, we should expect that local politicians would report themselves inferior in power to these two actors. That the local politicians share power with the administrative leaders is hardly surprising. This only supports the long-established fact that public bureaucracies in fact do have a great amount of power, also in local authorities (Mouritzen \& Svara 2002).

Next, it is interesting to note that local politicians rate themselves just as influential as the state level. This finding counters the notion advocated by several Norwegian researchers that Norwegian local authorities have lost much of their power in recent years due to strong state regulations (Fimreite \& Tranvik 2006; Fimreite 2003a \& 2003b; Tranvik \& Fimreite 2006). The reasons for this discrepancy may be both methodological and substantial.

Methodologically, the degree of local discretion may be measured in two different ways. One can be termed an "objective" strategy, simply counting the number of central government rules and regulations. If the number increases, it may be tempting to conclude that the remaining room for local discretion has decreased (Fleurke \& Willemse 2006). This is an "absolute" approach focusing on the total amount of state regulations, not on the amount of regulations relative to amount of responsibility delegated to the local level. While state regulations in Norway clearly have increased, so have the total resources been delegated to the municipal level (Hagen \& Sørensen 2006). If the total amount of resources delegated to the local level increases more than the amount of state regulations, the final result may indeed be more options for local discretion, not fewer. In addition, just counting the amount of central government regulations does not take into account the content of these regulations. Regulating, for instance, the content of primary schooling does not make other local discretionary decisions concerning primary schooling impossible. Asking more detailed questions concerning municipal tasks, for instance, on school structure, physical location, the prioritisation between schooling and other tasks, local politicians in Norway report a high 
degree of discretionary possibilities (Fimreite 2003a). Another way of measuring the degree of local authority leeway is to ask general questions about how local politicians perceive the general influence of the state level. Such a measuring clearly opens up for strategic answers. If we assume that local politicians always strive for more discretionary power over a municipal task, it becomes strategically reasonable to answer that the degree of central government control is too tight. In this study, such questions were also asked, and $74 \%$ of the respondents agreed to the proposition that the "legal control of municipalities in Norway is too strong" while $92 \%$ of them agreed on the proposition that "Norwegian municipalities are given too little economic leeway from the state". Still, when asking them to assess the influence of the state relatively to other actors, the picture changes to a larger degree of equality between local actors and the state. These traditional ways of measuring the degree of local autonomy may then systematically underestimate the actual room for discretion at the local level (Hansen 2000).

The findings in this study also counter the assumption that local political institutions are hollowed out by more informal political activity. On the contrary, politicians in this study perceive themselves very powerful in relation to informal political actors in the municipality. This does not, of course, exclude the possibility that external actors like the media and pressure groups are powerful. Rather, it supports the notion that these actors may be important, but not in the sense that they are supplanting the influence of the traditional political council. In more specific cases, on specific arenas, these actors may have a great power, as is shown in the many case studies documenting a municipality engaged in more horizontal networking with these actors (see Fimreite \& Medalen 2005 for Norwegian cases, Marcussen \& Torfing 2007 for European cases). This study does not dispute the fact that informal actors may be very important in specific situations, but when it comes to the core of the municipal tasks and activities, politicians seems to feel very much in control. In methodological terms, this finding underlines the problems associated with generalizing from single cases, even from many such cases. All cases may have the characteristics of "outliers", meaning that they are situated at the periphery of what municipalities usually do.

Finally, we see that the perceived power of international institutions is very low, on the verge of being non-existent. Again, this counters much of the "dominating discourse" in Norway where one of the main problems is viewed as being the loss of political power - at both central and local levels - due to supranational institutions (Østerud et al 2003). This finding should not, again, be interpreted in the way that international institutions have little or no power over Norwegian municipalities. Rather, the power of these institutions is exerted in an indirect manner in relation to Norwegian municipalities. As mentioned earlier, international institutions first and foremost interact with nation-states, and more rarely directly towards the local level (Christensen 1996). If these supranational institutions address local authorities, it is through regional councils and 
institutions. For actors at the local level, these differentiated and thus complicated interactions at the national-international level makes it difficult to distinguish clearly between what is nation-state policy and what eventually is the policy originating form international institutions. International policies are filtered through and translated by national institutions at the national level. Thus, part of the power of the state perceived by local politicians and administrators may in fact be indirect power exerted by international institutions.

To end on a more theoretical note, one should, when talking about the "hollowing out" of municipalities, also take into account that municipalities are not alike and that different sectors within the municipalities may differ greatly. Although the empirical data in this study only to a modest degree support it, it may be argued that some municipalities and some sectors within municipalities are more prone to be "hollowed out" than others. Municipalities with large resources and a healthy economy may exert greater resistance towards external pressures, and may be using less network governance and more hierarchy, simply because they have the resources to do so. This echoes the original notion found in the earlier writings of Rod Rhodes (especially 1994) where he works within a resource dependency framework. From his view, dependencies seemed to have changed from external actors being dependent on public organizations to a reversal of the dependency relationship where the public sector was more dependent on external actors.

Embedded in the original resource dependence perspective, as used by Pfeffer and Salancik (1978), is the idea that different organizations will experience different dependencies with their specific environment. This could result in organizations within the same business or field differing on how dependent they are on the environment. In short, dependencies vary. The same view should be present when studying organizational fields or whole sectors (in both private and public sectors), or when comparing different national contexts.

When studying to what degree traditional political institutions are hollowed out, one should take into account that dependencies can vary. Such differences can be analyzed on at least three levels: national, organisational, and divisional. Firstly, one should expect large variations between nations. Nations have different histories and traditions, as well as policies, including the amount of resources and discretion delegated to the local level. Sellers \& Lidstrøm (2007), for instance, display these differences clearly. They argue that what characterize the Scandinavian countries, in contrast to most other European countries, are first and foremost large responsibilities for the production of public welfare services. This gives Norwegian municipalities great responsibilities with great resources accordingly. One interpretation of the strong perception of autonomy among municipal politicians and administrators shown in this study may reflect the fact that they do in fact control large resources, more resources than most local politicians in other European countries. Controlling such large resources may also 
yield a situation where external parties are more dependent on the municipality than the other way around. In addition, Norway has not experienced such dramatic reforms of privatization and marketization as British municipalities. Production of important public services is still firmly placed under political control (Sørensen et al 2007). Thus, one should expect Norwegian municipalities to be much less hollowed out than their British counterparts. That the classical political centre is also very important in the implementation of policies in Norwegian municipalities is also shown empirically in the study by Hanssen \& Klausen (2007).

Secondly, also within nations, one should expect differences between municipalities. Reviving the original resource dependence perspective, one can view the political and administrative processes as several games between the local authority and a wide array of external actors (Long 1958). The character of these games, i.e., whether they are cooperative or conflictual, hierarchical or horizontal, will at least in part depend on the resources of each actor in the game. If we assume that municipalities may differ in the resources they control, and that the environment of the political and administrative nexus also varies in the control of resources, one should expect games to evolve differently in different municipalities. Local authorities where politicians and administrators control large human and financial resources, where they can mobilize expertise and knowledge within their own organisation, or maybe just a local authority with a strong culture and unity, will probably be less hollowed out than a weaker and more fragmented local authority. For instance, local authorities with the so-called "unhealthy economy", i.e., large deficits, are more heavily monitored and controlled by the state than local authorities with a strong economy, even placing those worst off in economic terms on a special surveillance list. On the other hand, municipalities with the presence of strong local media, strong interest associations or maybe just a resourceful citizenry (education, income, etc.), may create a situation where local authority power is more strongly challenged.

Thirdly, there may also be a great variance within local authorities. Local authorities are not homogenous and unitary organisations. With the large responsibilities delegated to the local level in Norway, there also follows a wide variety of tasks. Norwegian municipalities do mostly use their resources on service provision (schooling, health, roads, water, etc.), but do also have responsibilities for regulatory tasks (passing regulation for opening hours, authorizing buildings, etc.) and development tasks (community development, development of natural areas, etc.). The nature of the tasks may also cause different propensities to engage in governance structures. From empirical case studies, both in Norway and the rest of Europe (Fimreite \& Medalen 2003; Kooiman 2008; Marcusen \& Torfing 2007; Pierre 1998), it seems as though the tasks studied mostly fall into the "development" category. This is probably the task where local authorities have little formal powers, and where these powers have always been rather weak. If one focuses on the service provision, which is 
clearly the most important task for at least Norwegian local authorities, the formal powers will be much more clearly placed in the hands of local politicians (and service providers). The same would probably be the case if one should focus on regulatory tasks. Even if one focuses on one type of tasks, one should take into account that there may be large variations. For instance, not all service provision at the local level is controlled equally intensively by the central government. Some sectors where national unity is regarded as essential, for instance, schooling and social services are strongly controlled, while other sectors - specifically cultural activities and internal organisation - leave more discretionary power to local decision makers (Hansen 2000; Vabo \& Opedal 1997; Vabo 2002).

To sum it up, this study indicates that Norwegian local authorities seem to be far from being "hollowed out" because the traditional political centre still perceives their power to be extensive in relation to other actors in the municipality. It is impossible from a study covering such a short time span to say anything about the change over a long period of time. It may be said that the perceived power today is lower than twenty years ago, and thus it has lost some power. Regretfully, comparable studies going back in time do not exist, so it is impossible to know how local politicians perceived their power then. Still, data displayed in this study shows clearly that politicians feel far from being "hollow".

This study also calls for a more nuanced approach to the concept of governance, at least when it comes to empirically establishing the degree to which local authorities engage in the so-called governance structures. Indicated by several other studies (see Klijn 2007), traditional government structures are still very much present, and in many instances, government seems to be a more appropriate concept than governance. Several writers have underlined that "(...) the idea of a swift and clear-cut transition from government to governance is flawed" (Torfing 2007:3, see also Kooiman 2008; Pierre 2000). Traditional hierarchical government structures seem to exist parallel to more horizontally organised networks, indicating that traditional political power has not been entirely lost. This study contributes to the understanding why this transition from government to governance is far from clear-cut. One important reason may lie in the fact that traditional political and administrative institutions vary to the degree to which they are "hollowed-out". In some settings, as it may be true for the Norwegian municipalities, traditional powers may still be very much present, resulting in more traditionally and hierarchical government structures, while in some settings, traditional political and administrative institutions may have lost more power and thus would be more strongly characterised by networking and horizontal governance structures.

Empirical studies of the existence of governance structures would greatly benefit from a more explicit specification of when and under what circumstances governance structures arise, and when more traditional government structures 
seem to prevail. Reintroducing the concept of resource dependency, and looking for a variation across different national and institutional arrangements could give a more nuanced picture of the phenomenon of governance, and to what extent such structures are supplanting and/or complementing more traditional government structures. Such studies, focusing on a variation, may also be used for more normative purposes in the sense that one can be more able to define when and in what situations governance may be more efficient than traditional government, and when the activation of traditional hierarchy and government structures may be more appropriate.

\section{Notes}

${ }^{1}$ Linear regression analyses with more variables were also conducted, but the models all had low significance (F values) and little explained variance (R2). The single significant coefficients in the regressions analyses are very close to those of the bivariate correlations shown in table 5 .

\section{References}

Bachrach, P. \& Baratz, M. S. (1962) The Two Faces of Power, American Political Science Review, 56(4), pp. 947-952.

Bachrach, P. \& Baratz, M. S. (1963) Decisions and Nondecisions: An analytical Framework American Political Science Review, 57(3), pp. 632-642.

Banfield, E. C. (1961) Political Influence (New York: The Free Press).

Barry, B., (1980) Is it Better to be Powerful or Lucky? Part I, Political Studies, 28(2), pp. 183-194.

Barry, B., (1980), Is it Better to be Powerful or Lucky? Part II, Political Studies, 28(3), pp. 338352.

Baldersheim, H. (1998) 'Kommunal fristilling: Subsidiaritet på Norsk' In Grønli, T. \& Selle, P. (eds): Ein stat? Fristillingas fire ansikt. (Oslo: Samlaget).

Benjamin, C., Curry, T. J. \& Shwirian, K. P. (2003) Revisiting Norton Long's Ecology of Games: A Network Approach, City \& Community, 2(2), pp. 121-142

Berg, R. (2000) Den "gode" politiker. En studie av politiske ledelsesvardier i kommunerne. (Odense: Odense Universitetsforlag).

Bjørklund, T. \& Saglie, J. (2000) Lokalvalget i 1999. Rekordlav og rekordboy deltakelse. (Oslo: Institutt for samfunnsforskning, rapport nr. 12).

Bogason, P. (2000) Public Policy and Local Governance: Institutions in Post-Modern Society (Cheltenham, Edward Elgar).

Bonjean, C. M. \& Olson, D. M. (1964) Community Leadership: Direction for Research, Administrative Science Quarterly, 9(3), pp. 278-300.

Brass, D. J. (1984) Being in the Right Place: A Structural Analysis of Individual Influence in an Organization, Administrative Science Quarterly 29(4), 518-539

Christensen, T. (1996) Adapting to Processes of Europeanization: A Study of the Norwegian Ministry of Foreign Affairs (Oslo: University of Oslo, ARENA report no. 2).

Clegg, S. (1989) Frameworks of Power (London: Sage).

Clegg, S. (2006) The Bounds of Rationality: Power/History/Imagination, Critical Perspectives on Accounting. 17(7), pp. 847-863.

Clegg, S., D. Courpasson \& N. Phillips (2006) Power and Organizations (London: Sage).

Conway. W. J. (1973) Economic Dominants and Community Power - Reputational and Decisional Analysis, American Journal of Economics \& Sociology 32(3), pp. 269-282. 
Dahl, R. A. (1961) Who Governs? Democracy and Power in an American City (New Haven: Yale University Press).

Dowding, K., Dunleavy, P., King, D. \& Margetts, H. (1995) Rational Choice and Community Power Structures, Political Studies 43(2), pp. 265-277.

Du Gay, P. (2002) A Common Power to Keep Them All in Awe: A Comment on Governance, Cultural Values, 6(1-2), pp. 11-27.

Engelstad, F. (1999) 'Maktbegrepet etter Max Weber' In Engelstad, F. (ed): Om makt. Teori og kritike.k. (Oslo: Ad-notam Gyldendal).

Enz, C. E. (1989) The Measurement of Perceived Intraorganizational Power A MultiRespondent Perspective, Organization Studies 10(2), pp. 241-251.

Fimreite, A. L. (2003) Der hvor intet er, har selv keiseren tapt sin rett! Om lokalt folkestyre og rettigheter. (Bergen: Rokkanseteret).

Fimreite, A. L. (2003) Velferdsstat og lokaldemokrati - uforenlige størrelser?, Norsk Statsvitenskapelig Tidsskrift, 19, pp. 334-358.

Fimreite, A. L. \& Y. Flo (2002) Den besværlige lokalpolitikken, Nytt Norsk Tidsskrift, 19, pp. 310-321.

Fimreite, A. L., Y. Flo \& Tranvik, T. (2002) Lokalt handlingsrom og nasjonal integrasjon. Kommuneideologiske brytninger $i$ Norge $i$ et bistorisk perspektiv (Oslo: Makt- og demokratiutredningen, rapport nr. 50).

Fimreite, A. L. og T. Medalen, (2005) (eds) Governance i norske storbyer. Mellom offentlig styring og privat initiativ. (Oslo, Universitetsforlaget).

Fimreite, A. L. \& T. Tranvik (2006) Reform Failure, The processes of Devolution and Centralisation in Norway, Local Government Studies 32(1), pp. 89-107.

Flo, Y. (2003) Det lokale og det nasjonale. Statleg politike overfor det lokale og det regionale styringsverket frå 1900 til i dag (Oslo: Makt-og demokratiutredningen, rapport nr. 65).

Fleurke, F. \& Willemse, R.. (2006) Measuring Local Autonomy: A Decision-Making Approach, Local Government Studies 32(1), pp. 71-87.

Fredrickson, H. George., Brett Logan \& Curtis Wood (2003) Municipal Reform in MayorCouncil Cities: A Well Kept Secret, State and Local Government Review, 35(1), pp.7-14.

Friedrich, C. J. (1937) Constitutional Government and Politics (New York: Harper).

Gioia, D. \& Sims Jr., H. P. (1983) Perception of Managerial Power as a Consequence of Managerial Behaviour and Reputation, Journal of Management 9(1), pp.7-26.

Greenaway, J., B. Salter, and S. Hart (2007) How Policy Networks Can Damage Democratic Health: A Case Study in the Government of Governance, Public Administration, 85(3), pp. 717-738.

Grønmo, S. \& Løyning, T. (2003) Sosiale nettverk og okonomisk makt: overlappende styremedlemskap mellom norske bedrifter 1970-2000 (Bergen: Fagbokforlaget).

Hagen, T. P. \& Sørensen, R. J. (2006) Kommunal organisering. Effektivitet, styring og demokrati (Oslo: Tano Aschehoug).

Hanssen, G. S. \& J. E. Klausen (2007) 'Oslo Inner City Districts: Network Failure in the Face of Policy Success' In M. Marcussen \& J. Torfing, 2007, (eds): Democratic Network Governance in Europe (London, Palgrave Macmillan).

Hansen, T. (2000) 'Kommunal autonomi - hvor stort er spillerommet?' In Baldersheim, H. \& Rose, L. E. (eds): Det kommunale laboratorium. Teoretiske perspektiver på lokal politikk og organisering (Bergen: fagbokforlaget).

Hansen, T., S. Hovik \& J. E. Klausen (2000) Stortinget som lokalpolitisk aktor. NIBRs-Pluss serie nr. 3 (Oslo: NIBR).

Hernes, G. (1978) 'Det medievridde samfunn' I G. Hernes og W. Martiniussen: Demokrati og politiske ressurser (Oslo: NOU:7) 
Hirst, P. (2000) 'Democracy and Governance' In J. Pierre (ed): Debating Governance (Oxford, Oxford University Press).

Hovik, S. \& Stigen, I. M. (2004) Kommunal organisering 2004 (Oslo: NIBR), notat nr. 124.

Hunter, F. (1963) Community Power Structures. (Chapel Hill: University of North Carolina Press). Jacobsen, D. I. (1997) Administrasjonens makt (Oslo: Fagbokforlaget).

Jacobsen, D. I. (2003) Politico-Administrative Conflict at the Local Level: Determined by the Degree of Central Government Regulation?, Local Government Studies, 29(4), pp. 95-116.

Jacobsen, D. I. (2007) Fragmentering og integrasjon i norske kommuner - politisk retrett eller vitalisering?, Kommunal Ekonomi och Politike, 11, pp. 33-63.

Johnsen, A. (1999) Performance Measures in Local Government. Dr.Oecon dissertation (Bergen: $\mathrm{NHH})$.

Jun, S. P. \& Armstrong, G. M. (1990) The Bases of Power in Churches: An Analysis from a Resource Dependence Perspective, Social Science Journal 34(2), pp. 105-131.

Kaufman, H. \& Jones, V. (1954) The Mystery of Power, Public Administration Review 14, pp. 205-212.

Kjær, A. M. (2004) Governance. Key Concepts. (Malden, Polity Press).

Klijn, E-H. (2008) Governance and Governance Networks in Europe, Public Management Review, 10(4), pp. 505-525.

Kooiman, J. (1993) Modern Governance: Government-Society Interactions (London: Sage).

Kooiman, J. (2008) Governing as Governance (London: Sage).

Krackhardt, D. (1990) Assessing the Political Landscape: Structure, Cognition, and Power in Organizations, Administrative Science Quarterly 35(2), pp. 342-369.

Lascoumes, P. \& P. le Gales (2003) 'Interest Groups and Public Organizations in Europe' In B. G. Peters \& J. Pierre (eds): Handbook of Public Administration (London: Sage).

Lively, J. (1975) Democracy (Oxford: Basil Blackwell).

Long, N. L. (1958) The Local Community as an Ecology of Games, American Journal of Sociology 64(3), pp. 251-261.

Lowndes, V. \& Skelcher, C. (1998) The Dynamics of Multi-Organizational Partnerships: An Analysis of Changing Modes of Governance, Public Administration, 76(2), pp. 313-333.

Lukes, S. (1974) Power: A Radical View (Basington: Macmillan).

Lægreid, P. \& Roness, P. G. (1998) 'Frå einskap til manfold - Eit perspektiv på indre fristilling I statsforvaltningen' In T. Grønli \& P. Selle (eds): Ein stat? Fristillingas fire ansikt. (Oslo: Samlaget).

March, J. G. (1988) 'The Power of Power' In March, J.G.: Decisions and Organizations (Oxford: Basil Blackwell).

Marcussen, M. \& Torfing, J. (eds) (2007) Democratic Network Governance in Europe (London, Palgrave Macmillan).

Mintzberg, H. (1983) Power in and around Organizations (Englewood Cliffs: Prentice Hall).

Mortensen, T., Roppen, J. \& Ødegård, A-K. (1995) Lokalpolitikek og media. Ein for-studie av media si betydning for lokalpolitikken. Arbeidsrapport nr. 8 (Volda: Høgskolen i Molde/Møreforskning).

Mouritzen, P. E. \& Svara, J. H. (2002) Leadership at the Apex. Politicians and Administrators in Western Local Governments (Pittsburg: University of Pittsburgh Press).

Nordby, T. \& Veggeland, F. (1999) Lovgivningsmyndighetens suspensjon: Stortingets rolle under EØS-avtalen, Tidsskrift for samfunnsforskning 40, pp. 87-109.

Offerdal, A. (2003) Politisk deltakelse - er den så nøye da?, Norsk Statsvitenskapelig Tidsskrift 19, pp. 360-376.

Offerdal, A. \& F. Kjellberg (1997) Lokalpolitikk og forvaltning: Sentrale utviklingslinjer i norsk kommunalforskning i etterkrigstiden, Norsk Statsvitenskapelig Tidsskrift 13, pp. 279-298.

Olsen, J. P. (1983) Organized Democracy (Oslo: Universitetsforlaget). 
Olsen, J. P. (1988) 'Representativitet og politisk organisering' In Olsen, J.P: Statsstyre og institusjonsutforming (Oslo: Universitetsforlaget).

Opedal, S., Stigen, I. M. \& Laudal, T. (2002) Flat struktur og resultatenheter (Oslo: NIBR), rapport 2002:21.

Perrow, C. (1970) 'Departmental Power and Perspectives in Industrial Firms' In Zald, M. N. (ed): Power in Organizations. (Nashville: Vanderbilt University Press).

Peters, B. G. (2001) The Politics of Bureaucracy (5 $5^{\text {th }}$ ed) (London, Routledge).

Pfeffer, J. (1981) Power in Organizations (Cambridge MA: Ballinger).

Pfeffer, J. (1992) Managing with Power: Politics and Influence in Organizations (Boston: Harvard Business School Press).

Pfeffer, J. \& G. Salancik (1978) The External Control of Organizations (New York, Harper \& Row).

Pierre, J. (1993) Legitimacy, Institutional Change, and the Politics of Public Administration in Sweden, International Political Science Review, 14(4), pp. 387-401.

Pierre, J. (1998) 'Public-private partnerships and urban governance - Introduction' In J. Pierre (ed): Partnership in urban governance. European and American Experiences (Basingstoke: Palgrave).

Pierre, J. (2000) 'Introduction: Understanding Governance" In J. Pierre (ed): Debating Governance. Authority, Steering, and Democracy (Oxford, Oxford University Press).

Polsby, N. W. (1979) Empirical Investigations of the Mobilization of Bias in Community Power Research, Political Studies 27(4), pp. 527-541.

Presthus, R. (1964) Men at the Top: A Study in Community Power (New York: Oxford University Press).

Rhodes, R. A. W. (1994) The Hollowing-Out of the State - the Changing Nature of the Public Service in Britain, Political Quarterly, 65(2), pp. 138-151.

Rhodes, R.. A. W. (1996) The New Governance: Governing without Government, Political Studies, 44(4), pp. 652-667.

Rhodes, R. A. W. (2007) Understanding Governance: Ten Years on, Organization Studies, 28(8), pp. 1243-1264.

Saglie, J. (2005) 'Avslutning. Lokaldemokratiet - bedre enn sitt rykte' In Saglie, J. \& Bjørklund, T. (eds): Lokalvalg og lokalt folkestyre (Oslo: Gyldendal Akademisk).

Saglie, J. \& T. Bjørklund (2005) (eds) Lokalvalg og lokalt folkestyre (Oslo: Gyldendal Akademisk).

Sellers, J. M. \& A. Lidstrøm (2007) Decentralization, Local Government, and the Welfare State, Governance - An international Journal of Policy and Administration, 20(4), pp. 609-632.

SOU (1990:44), Demokrati och makt $i$ Sverige. Maktutredningens hovudrapport.

Stone, C. N. (1989) Regime Politics. Governing Atlanta 1946-1988 (Lawrence, University of Kansas Press).

Stone, C. N. (2006a) Preemptive Power: Floyd Hunter's "Community Power Structure" Reconsidered, American Journal of Political Science 32(1), pp. 82-105.

Stone, C. N. (2006b) Power, Reform and Urban Regime Analysis, City and Community, 5(1), pp. 23-38.

Sussmann, G. (1997) Communication, Technology and Politics in the Information Age (London: Sage).

Sørensen, E. \& Torfing, J. (2007) (eds) Theories of Democratic Network Governance (London, Palgrave McMillan).

Sørensen, R. Borge, L-E. Fjeldstad, M. Monkerud, L. C. Pallesen, S. \& Vabo, S. I. (2007) Omstilling og utvikling $i$ norske kommuner. Mye skrik og lite ull?, Forskningsrapport 3/2001 (Oslo, Handelshøyskolen BI).

Togeby, L. Andersen, J. G. Christiansen, P. M. Jørgensen, T. B. \& Vallgårda, S. (2003) Magt og demokerati i Danmark - hovedresultater fra magtutredningen. (Aarhus: Aarhus universitetsforlag).

Torfing, J. (2007) 'Introduction: Democratic Network Governance' In M. Marcussen \& J. Torfing (eds): Democratic Network Governance in Europe. (Houndmills: Palgrave). 
Tranvik, T. \& Fimreite, A. L. (2006) Reform Failure: The Process of Devolution and Centralisation in Norway, Local Government Studies, 32(1), pp. 89-107.

Trondal, J. (2007) The Public Administration Turn in Integration Research, Journal of European Public Policy, 14(6), pp. 960-972.

Vabo, S. I. (2002) Koordinering og politisk styring: en studie av nye organisasjonslosninger $i$ norske kommuner. Dr.polit avhandling, (Oslo: Institutt for statsvitenskap, Universitetet i Oslo).

Vabo, S. I. \& Opedal, S. (1997) Oppfatninger av forboldet mellom staten og kommunene. En dokumentstudie. (Oslo: NIBR) notat nr. 112.

Vabo, S. I. \& Stigen, I. M. (2000) Kommunal organisering 2000 (Oslo: NIBR) notat nr. 128.

Walgrave, S. \& Van Aelst, P. (2006) The Contingency of Mass Media's Political Agenda Setting Power: Toward a Preliminary Theory, Journal of Communication, 56(1), pp. 88-109.

Wolfinger, R. E. (1962) A Plea for a Decent Burial, American Sociological Review, 27, pp. 848-854.

Ødegård, A-K (1996) Demokrati gjennom lokalavisa. Sambandling og innflytelse i kommunalsaker mellom journalister, kommunal styresmakter og innbyggjarar. Arbeidsrapport nr. 30 (Volda: Høgskolen i Molde/Møreforskning).

Ødegård, A-K (1997) Demokratisk dialog gjennom lokalavisa. Ei vurdering av lokalavisa si rolle som formidlingskanal mellom kommune og innbyggjar. Notat 4/97 (Volda: Høgskolen i Molde/Møreforskning).

Øgård, M. (2000) 'New Public Management - markedet som redningsplanke' In H. Baldersheim \& L. E. Rose (eds) Det kommunale laboratorium. Teoretiske perspektiver på lokal politike. og organisering (Oslo: Fagbokforlaget).

Østby, H., 2000, Hvem eier norske massemedier?, rapport nr. 25 (Oslo: Makt-og demokratiutredningen).

Østerud, Ø., Engelstad, F. \& Selle, P. (2003) Makten og demokratiet. En sluttbok fra Makt- og demokratiutredningen (Oslo: Gyldendal Akademisk). 